\title{
EMBRACING, AMBIGUITIES.
}

\author{
by
}

\author{
Laura Levitt
}

\begin{abstract}
Laura Levitt works as an Assistant Professor of Religion at Temple University, teaching also in the Women's Studies Program. Her writing attends to feminist theory and contemporary Jewish culture. She is the author of the forthcoming book Ambivalent Embraces: Jewisb Feminist Identities as Home (New York: Routledge).
\end{abstract}

Perhaps "embrace" is an odd way to explain a methodological turn in one's work, but it captures well the way I work with texts. According to The American Heritage Dictionary, to "embrace" means:

To clasp or hold with arms, usually as an expression of affection. . . To surround; enclose... . To twine around... To include as part of something broader. ... To take up willingly or eagerly. ... An act of holding close with the arms, usually as an expression of affection; a hug. . . An enclosure or encirclement. ... Eager acceptance. ${ }^{1}$

Implicit in this definition is a desire, an attraction that calls for a response. An embrace is such a response. But in acting on such a desire, there is already a tension. Although an embrace can be a loving gesture, a tender act of affection, or protection, it has other connotations. To hold is also to assume control over another, even, and perhaps especially, the other who is the object of one's affection. In the American Heritage to "embrace" is to surround or enclose. One may hold on too tight, not allowing the other enough space to breathe and to grow on their own. When I think about being entwined I worry about the damage done by vines like kudzu that take over all that comes into their grasp. These vines kill the trees and bushes within their embrace.

${ }^{1}$ The American Heritage Dictionary of the English Language, Third Edition, (Boston, Houghton, Mifflin Company, 1992). 
Reading is about desire, and about different kinds of embraces. In reading a text, something brings you in, captures your imagination, hooks you. To embrace a text is to give yourself to these desires. This is a joy, but with dangers. One danger is holding on too tightly; the text loses its distinct character and becomes a reflection of the reader. The reader takes the text into herself. It becomes an extension of her. Another danger, an inversion of the first: the reader loses herself in the text. Whereas in the first danger, the text gets swallowed, here the reader's difference dissolves. She is reduced to another instance of the text's argument. In becoming the text, she loses her own voice by taking on that of the text. Both of these forms of reading blur boundaries. Distinctions between reader and text are lost.

This blurring of distinctions gets tricky when such reading is accompanied by, and part of, one's writing. In writing we stake out positions and this feels risky. Yet, what goes on in forms of writing-such as academic scholarship-that depend on citations of other writers' texts? Sometimes finding and staking out one's own positions happens in response, while reading texts with similar commitments. Their similarities offer a kind of (em)brace. They hold us up as we attempt to take a stand, especially for the first time. Citations of other people's writing can brace our own argument. They provide weight, authority, and precedent. But sometimes in this process, one of the writers gets lost. As readers who write about other people's writing, we can lose our own voices, holding on too tightly to the authority of other people's writing. And so in writing this essay, I find myself a bit wobbly. There are texts that I want to bring into this discussion, passages I want to cite as proof for what I am saying. For the moment, I will resist the temptation. I will let my words stand alone.

I have been able to find my voice as a writer by reading and engaging with the texts of others. The text that speaks to me right now-pushing through the seams of my essay with such force that I can barely keep myself from quoting it at length-is Susan Rubin Suleiman's Risking Who One Is: Encounters with Contemporary Art and Literature. ${ }^{2}$ In her introduction Suleiman writes about how she reads and writes about contemporary art and literature. As she explains, in writing this book she became aware of the fact that she was "constructing one version of the shape of my own life." She continues:

${ }^{2}$ Susan Rubin Suleiman, Risking Who One Is: Encounters uith Contemporary Art and Literature (Cambridge: Harvard University Press, 1994). 
Since these are all critical essays dealing with the work of others . . ., they are not what I would call "straight autobiography." Rather, they are a form of mediated autobiography where the exploration of the writer's self (which I take to be a defining characteristic of autobiography) takes place not directly but through the mediation of writing about another. (p. 3)

What I love about this passage is my sense of recognition. I identify with her narrative voice. I recognize myself in Suleiman's writing, and, yet there is something in this identification that feels uncomfortable. Before writing this portion of this essay I discussed it with Miriam. I explained that I was thinking about the notion of embracing texts, that I was pulling out the tension in critical practices of reading, writing, and citation, looking closely at the relations between the text and me. But I couldn't resist reading her this passage from Risking Wbo One Is. I wanted her to understand what I was doing by hearing it in Suleiman's voice. I assumed that my point would be obvious. It was not. Instead, I discovered a difference-that my enthusiasm was my own. Suleiman's text spoke to me, but what I heard was not self-evident. Reading the passage to Miriam did not have the effect on her that it had had on me. Despite my desire for clarity through citation, my point was lost as I translated my argument into a reading from Suleiman's text.

Miriam liked what I had been telling her about my argument. She didn't need the citation; I did. The fact that she did not see me as clearly as I had seen myself reflected in Suleiman's text left me to wonder about the differences between my project and Suleiman's. What is it that draws me in? At what specific point did I see myself most clearly in her writing? I saw myself in Suleiman's discussion of the ambivalence of mediated autobiographical writing. As she explains, her essays are "a form of mediated autobiography where the exploration of the writer's self ... takes place not directly but through the mediation of writing about another" (p. 3). In this particular sentence, I found both the desire-and the difference. When I write about embracing texts, I am not talking about "autobiographical" writing. Although an attraction to the autobiographical is already present in my explanation of what it might mean to "embrace" a text, I am not solely concerned with "the exploration of the writer's self." I don't want to efface the self who always reads and writes from somewhere, who is already positioned in relation to particular texts, albeit in various and contradictory ways. At issue is not so much reading my self, but about reading with delicacy about lots of things as my self.

I read, write, and teach about Jewish texts as varied as a standard rabbinic ketubbah, Napoleon's questions to the Jewish notables, and a 
series of poems by Irena Klepfisz. ${ }^{3}$ With all of these, at issue is how to be in a relationship of embrace in which neither partner is effaced, where the "text" doesn't have any essential authority, nor can I entirely be its voice. Rather, the textual embrace I desire acknowledges the tensions in reading and writing about texts, it lets doubled voices converse together in both their similarities and in their differences. In writing about various Jewish texts, I don't wish to collapse them into the autobiographical, into something about me. This would mean a loss of all that is not "me" in these texts. And yet, this is not an all-or-nothing proposition. Standing in relation to most Jewish texts, mine is an ambivalent embrace. Reading Jewish texts, I wish to write in a way that maintains my voice, while I write about the interplay between familiarity, intimacy, and distance between me -a certain kind of Jewish feminist-and Jewish texts.

Acknowledging these tensions is part of what it has meant for me to engender Jewish knowledges through an embodied critical practice. By reading and writing about these texts as myself, I resist taking on the (albeit various) roles of "reader" demanded by certain Jewish reading practices. I cannot read from the position of the normative, masculine reader, the partner still presumed to be central to Jewish study. From another angle, the fiction of objectivity looms large over this whole conversation about reading and writing. It remains a critical authorizing practice in a Jewish Studies still loyal to its roots in the enlightenment ethos of the Wissenschaft des Judentums. To think about a self who reads and writes in relation to others is to imagine a self who has a stake in certain readings of-and relations to-Jewish texts. To resist both the familiarity of "tradition" and the allure of "objectivity" requires tremendous discipline.

\footnotetext{
${ }^{3}$ See Laura Levitt, Ambivalent Embraces: Jeuish Feminist Identities as Home (New York: Routledge, forthcoming) and "Reconfiguring Home: Jewish Feminist Identity/ies," in T. M. Rudavsky, ed., Gender and Judaism: The Transformation of Tradition (New York: New York University Press, 1995), pp. 39-49.
} 